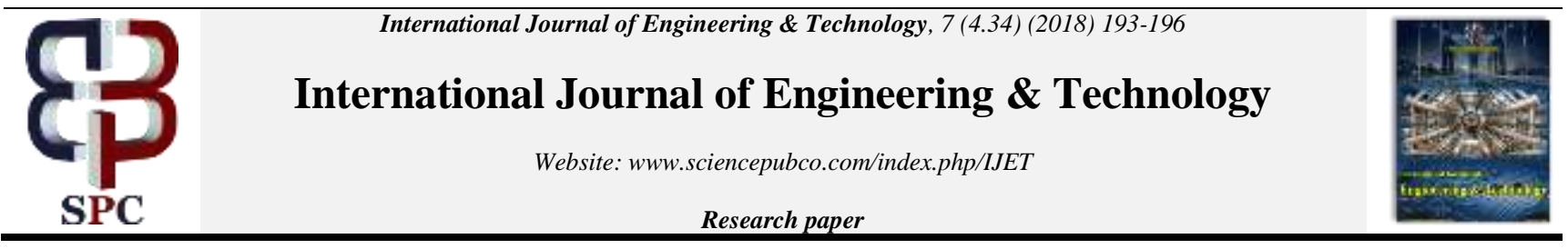

\title{
Relationship of Job Satisfaction and Demographic Variables in Terengganu Public Universities
}

\author{
Nur Amalyna Radzali, Norsuhaily Abu Bakar* \\ Faculty of Applied Social Sciences, Universiti Sultan Zainal Abidin, Gong Badak Campus, 21300 Kuala Nerus, Terengganu, \\ Malaysia \\ *Corresponding author Email: norsuhaily@unisza.edu.my
}

\begin{abstract}
The study on job satisfaction among academic staff at Public Universities in Terengganu is aimed at identifying the level and factors towards their job satisfaction while serving at public universities. This study involved 298 respondents voluntarily. The characteristics of the collected respondents' demographic variables are divided into 9 sections consisting of gender, age, level of education, position of status, service period, position, and other positions within the department. The involved respondents are based on the different levels of academic staff ranging from Assistant Lecturer, Lecturer, Senior Lecturer, Associate Professor, and Professor. Among these respondents were those holding various administrative posts such as Central Director, Dean, Deputy Dean and Head of Department or Head of School. All of the demographic information of these respondents are collected through a survey distributed to them. The results of this finding have been analysed in the form of tables based on the number and percentage of respondents.
\end{abstract}

Keywords: job satisfaction; demographic variables; academic staff.

\section{Introduction}

The study on job satisfaction among academic staff at Terengganu public universities was involved 298 respondents comprising of academic staff from three Public Universities in Terengganu: Universiti Sultan Zainal Abidin, Universiti Malaysia Terengganu and Universiti Teknologi MARA, Kuala Terengganu. Demographic variables such as gender, age, education, level of post, service period, position and other positions in the department are presented in table form based on the number and percentage of respondents.

\section{Research Problems}

The Ministry of Higher Education recorded a total of 31, 877 academic staff at all Public University in Malaysia. With this growing number, future academic workforce at the Institute of Higher Education (IPT) should be prepared to face the challenges of globalisation, intense competition and the latest technological changes. Labor in IPT will always face the challenge and be guided by the country's aspirations as well as the strength of existing policies [1]. Quality academic staffs at universities are the most important institution-based factor in determining student outcomes. Given the role of academic staff is important in improving the quality of education, the main focus of the Higher Education Ministry (KPT) is to continue efforts in empowering the Institute of Higher Education (IPT) [2]. 10 main aspects have been outlined, one of which is the quality strengthening of academic staff [1]. In this respect, KPT has taken a thorough study on the factors that could contribute to the effectiveness of the academic preparation. The action and planning motion will be set in 2010 and subsequent years [2].

Low-performance officers indicates that the Annual Performance Evaluation Report (LNPT) for the Commonwealth Service Officers and Implementing Group Members (AKP) including Education Service Officers (PPPs) are housed in cadres ( positions belonging to a Ministry or Department created by various Agencies based on its requirements but its filling is done and controlled by the Head of Service ), loans, transfers and the equivalent of less than $60 \%$ or the Score of the Integrated Assessment of Education Service Officers (PBPPP) for Education Service Officers (PPPS) is less than 60\%; or Key Performance Indicator (KPI) achievement under the target of the KPI performance evaluation [3]. In line with the wishes of the Malaysian Education Development Plan (PPPM) 2013-2025; to ensure the delivery of educational services are not affected, the Ministry of Education will take action to certify the termination of the profession for low- performing officers through procedures based on the facts of each case [4]. This is in line with Regulation 49, Public Officers (Conduct and Discipline) Regulations 1993 (PU (A) 395/1993) which is after the Government takes the performance, conduct, usefulness of officers to service, the terms of service and all other matters determined by the Government into consideration [4].

Considerations are also made in implementing this policy, whether the disciplinary action is more appropriate to be taken on an officer based on misconduct or through the Exit Policy. According to this circular, officers who are currently under disciplinary action proceedings and low scores (59.99\% and below) of the implementation of the Exit Policy shall be conducted on the officer in view of any action made under the Circular (Circular 
No. 7/2015). It does not prevent the Disciplinary Authority from taking any disciplinary action or surcharge on such officer [5].

The implementation of this separation policy will be able to maintain a committed and high performing civil servant to enable education services improve its service quality and competitiveness in facing the current environmental challenges to meet with the requirements of the Malaysia Education Development Plan (PPPM) 2013-2025 [4]. Exit Policy introduced through the 11th Malaysia Plan (RMK-11) is aimed at rationalising the public sector and justifying the size of public civil service in the organization. However, this policy is not intended to reduce the workforce in the organisation, but to ensure civil servants remain competent in carrying out their duties in the department [5].

At the Public University, various efforts are undertaken by the administration of the university's management body to meet the satisfaction of its employees and ensure that the academic workforce continues to be competent and strives to improve its performance. However, there is still conflict among workers such as young academicians and senior academic staffs on issues of job dissatisfaction [6]. Among them are the opportunity to attend training programs and courses, the opportunity to pursue higher education at home or abroad, promotional opportunities as well as other facilities provided such as medical facilities and vehicle loans [7]. However, whether this incentive affects job satisfaction among academicians is still a problem.

In addition, wage issues are also one of the causes of dissatisfaction with academic work. The Public Service Department (PSD) stated that it will review all issues relating to the allegations of 35,000 academic public academic staff not renewed for the last 15 years in a press statement [7]. Malaysian Academic Association of Malaysia (MAAC) President Prof Datuk Dr Mohd Idrus Mohd Masirin claims that academic staff is less attentive than teachers who often enjoy new incentives [8]. He also noted that the quality of academic services was feared to be affected when the service schemes and salaries had not changed over the last 15 years, and were lagging behind other civil servants [8]. In [9] stated in his theory that job satisfaction is the positive attitude and feeling that employees have on their work. This job satisfaction depends on several factors and varies greatly between one employee and another. The measurement of the level and the job satisfaction factor in this study was based on the Job Descriptive Index (JDI) instrument established by [10]'s work and was modified for local use. This study will try to identify the level and relationship between job satisfaction factors as stated in JDI such as working conditions, promotional opportunities, salaries, supervision and colleagues with job satisfaction at academic staff at Public University. This study will also identify the demographic characteristics of workers such as gender, age, marital status and length of service, rank and salary.

\section{Research Questions}

The research questions are as follows:

i. What are the demographic characteristics such as gender, age, marital status, length of service, rank and academic salary in Public University?

ii. To what extent is the level of job satisfaction among academic staffs at Public University?

\section{Hypothetical Studies}

The hypotheses to be tested in this study are based on questions and objectives of the study. The hypotheses are as follows:

H1: The academic practitioners' satisfaction at Public University is at a high level.
$\mathrm{H} 2$ : There is a significant relationship between working atmosphere, promotional opportunities, salary, supervision, and colleagues with the satisfaction of academic staffs of the Public University.

\section{Instruments}

This study uses questionnaires divided into three sections, part A involving respondents' demographic information, part B questions on the level of job satisfaction self-developed by the researcher and part $\mathrm{C}$ comprises of questionnaires related to job satisfaction factors that were translated from' Job Descriptive Index '(JDI) by Smith, Kendall and Hulin (1969), based on Herzberg Two Factors Theory [11].

Information from part A comprised of 8 characteristics of the respondents' demographic. This includes gender, age, marital status, educational information, status of position, service period, rank and salary. Meanwhile, part B discusses on the level of job satisfaction and have provided 10 questions and uses 5 points of the Likert scale which is 'very disagreeable', 'disagreeable', 'uncertain', 'agreeable' and 'strongly agreed'. For part C, the question consists of a breakdown of job satisfaction factors translated from 'Job Descriptive Index' (JDI) by [11] which include factors of working environment, promotional opportunities, salaries, supervision and co-workers. The questionnaire also uses 5 points of the Likert scale which is very 'disagreeable', 'disagreeable', 'uncertain', 'agreeable' and 'strongly agreed'.

\section{Results and Discussion}

\subsection{Sample Profile by Gender}

The information in Table 1 shows the sample profiles by gender. Of the 298 respondents involved in this study, 118 persons or 39.6 percent were male, while 180 or 60.4 percent were female. This shows that the number of respondents from women is more than the male respondents in this study.

Table 1: Sample Profile by gender

\begin{tabular}{|c|c|c|}
\hline & Quantity & Percentage \\
\hline Men & 118 & 39.6 \\
\hline Women & 180 & 60.4 \\
\hline Total & 298 & 100.0 \\
\hline
\end{tabular}

Several studies on gender factors and job satisfaction from previous researchers had obtained different findings. In [12] found that job satisfaction between men and women does not differ much. While, the study by [13] identified that there was no significant difference between male and female teachers in relation to job satisfaction.

On the other hand, the findings from [14] show that female employees experience higher levels of job satisfaction than men. While, the research by [13] had found no significant difference between male and female teachers in relation to job satisfaction.

Further analysis on relationships between gender and work productivity had identified that men $(58.7 \%)$ were more productive than women [15].

Through the Women, Family and Community Statistics Report, 2016, the ratio of the people working in the professional sector by gender is $7.4 \%$ male: $15.3 \%$ female. This indicates more women employees in the professional field than male employees. Below is the schedule of Academic Power at Public University from 2013 2015 released by [16].

Table 2: Number of academic staffs at public universities from $2014-2015$

\begin{tabular}{|c|c|c|c|c|c|c|}
\hline Year & \multicolumn{3}{|c|}{2014} & \multicolumn{3}{|c|}{2015} \\
\hline Gender & Professor & Associate Professor & Lecturer & Professor & Associate Professor & Lecturer \\
\hline Men & 1668 & 2562 & 9457 & 1561 & 2172 & 9542 \\
\hline
\end{tabular}




\begin{tabular}{|c|c|c|c|c|c|}
\hline Women & 623 & 1926 & 12608 & 639 & 12833 \\
\hline Total & 2291 & 4488 & 22065 & 2200 & 1578 \\
\hline \% of women From total & $27.2 \%$ & $42.9 \%$ & $57.1 \%$ & $29.0 \%$ & 3750 \\
\hline
\end{tabular}

\subsection{Sample Profile by Age}

According to the age profile, 18 respondents $(6.0 \%)$ were $20-30$ years old, 121 people $(40.6 \%)$ were $31-40$ years old, 112 people (37.6\%) were $41-50$ years old, while 43 persons (14.4\%) aged 5160 , and 4 persons $(1.3 \%$ ) are more than 61 years old.

Table 3: Sample Profile by Age

\begin{tabular}{|c|c|c|}
\hline \multicolumn{1}{|c|}{ Table 3: Sample Profile by Age } \\
\hline & Quantity & Percentage \\
\hline 20-30 years & 18 & 6.0 \\
\hline 31-40 years & 121 & 40.6 \\
\hline 41-50 years & 112 & 37.6 \\
\hline 51-60 years & 43 & 14.4 \\
\hline 61 years and above & 4 & 1.3 \\
\hline Total & 298 & 100.0 \\
\hline
\end{tabular}

In terms of sample profiles according to age, there are also respondents aged 61 years and above have passed the compulsory retirement age. These are the academic classes who continue to be given the opportunity to serve on the basis of their expertise.

The research findings by [13] show that age is positively associated with job satisfaction. The findings of this study conclude that veteran employees can adapt to the needs of the work as compared to young employees. This makes them more satisfied than the young employees [13].

The findings of the study conducted by [17] has found that the lecturers aged from 30 to 39 years $(48.4 \%)$ were the most productive compared to other lecturers. While the majority of lecturers aged from 20 to 29 years old are unproductive at work (51.3\%) [18].

According to [19], managing aged and senior employees require a humanistic approach to their achievement and commitment for them to be sustained. Among them are open communication systems so that all ideas, views, directions, changes, strategies and organisational plans can be shared.

\subsection{Sample Profile by Education Level}

Referring to Table 5, it can be seen that the majority from the highest level of respondents are Ph.D. Doctors which are 135 persons $(45.3 \%)$. Followed by a total of $124(41.6 \%)$ Masters, 37 $(12.4 \%)$ Degrees and $2(0.7 \%)$ others.

Table 4: Sample Profile by Education Level

\begin{tabular}{|c|c|c|}
\hline & Quantity & Percentage \\
\hline Degree & 37 & 12.4 \\
\hline Masters & 124 & 41.6 \\
\hline Ph.D & 135 & 45.3 \\
\hline Others & 2 & 0.7 \\
\hline Total & 298 & 100.0 \\
\hline
\end{tabular}

In this study, the respondents' profile is according to the level of education which include the Bachelor's Degree, Master's Degree, Doctorate Degree and others. Education level can also affect the individual's belief in identity and self-worth [20]. Recent studies have also shown the positive impact of education on salary and promotion [21].

The following table shows the number of academic staff according to the level of education up to 2015 released by Higher Education Statistics: Ministry of Higher Education [4].

Table 5: Number of academic staff by educational level up to 2015

\begin{tabular}{|c|c|c|c|}
\hline \multirow{2}{*}{ Level of Education } & \multicolumn{2}{|c|}{ Staff } & \multirow{2}{*}{ Total } \\
\cline { 2 - 3 } & Men & Men & \\
\hline Doctorate Degree & 7,494 & 6,431 & 13,925 \\
\hline Master Degree & 6,168 & 9,131 & 15,299 \\
\hline Bachelor Degree & 970 & 1,420 & 2,390 \\
\hline Diploma & 75 & 34 & 109 \\
\hline Other & 89 & 65 & 154 \\
\hline
\end{tabular}

Employees with higher education level will have more career options and will have the opportunity to earn higher wages [22]. Investment in self-development such as education and training has been the most consistent determinant of career success for an individual [23].

Continuous research has consistently found a positive relationship between the level of education and career success. For example, studies conducted by some experts in the field related to career exposure also explains the positive relationship between career success and education level [23]. They find that one's level of education can increase individual income [23].

Recent studies have also shown a positive impact on education levels on salaries and promotion [21].

Education level can also affect the individual's belief in identity and self-worth [20]. From these studies, it is clear that the level of education affects one's work quality. The knowledge and skills acquired through education will lead a person to believe that they are more valuable in the workplace. Hence it is expected that having a high level of education will lead to the success of academic career at university [24].

The Malaysian government has focused on efforts to improve the quality of academic staffs. One of the government's efforts is to set $75 \%$ of the academic staff of the university to have a Doctorate in Philosophy (PhD). As a first step, the government has set $60 \%$ of academic staff to have a Doctorate in PhD in 2010 [4].

But by 2010 , only $49.1 \%$ of academicians in all university studies have a degree. This is a challenge for Malaysian research universities in bringing the nation to the center of excellence in knowledge in Southeast Asia. Furthermore, the success of obtaining the highest degree of Doctorate in Philosophy $(\mathrm{PhD})$ is an important determinant to the success of academic career [25]. Therefore, those who undergo the process of study for the Doctorate of Philosophy (PhD) level have a higher level of career success as they have a strong formal research base [26].

\subsection{Sample Profile by Position}

For the job profile, the majority of the respondents involved were from Lecturers with 97 (32.6\%). Followed by a total of 92 people $(30.9 \%)$ from the Senior Lecturer, a total of 34 people $(11.4 \%)$ from Assistant Lecturer, 30 (10.1\%) from Lecturers, $20(6.7 \%)$ from Associate Professor, $14 \%$ ) from the Professor, and 11 $(3.7 \%)$ from others.

Table 6: Sample Profile by Position

\begin{tabular}{|c|c|c|}
\hline \multicolumn{2}{|c|}{ Table 6: Sample Profle by Position } \\
\hline Tutor & Quantity & Percentage \\
\hline Assistant Tutor & 30 & 10.1 \\
\hline Lecturer & 34 & 11.4 \\
\hline Assistant Lecture & 97 & 32.6 \\
\hline Associate Professor & 92 & 30.9 \\
\hline Professor & 20 & 6.7 \\
\hline Other & 14 & 4.7 \\
\hline Total & 11 & 3.7 \\
\hline & 298 & 100.0 \\
\hline
\end{tabular}

For the profile of respondents, seven types of posts have been classified as Tutor, Assistant Tutor, Lecturers, Senior Lecturers, Associate Professors, Professors and others such as academic staffs. Based on the findings, the majority of the respondents involved were Lecturers with a total of 97 (32.6\%).

According to the statistical report by the Department of National Statistics: The Ministry of Higher Education 2014 [27] data shows that the academic staffs at public universities in three universities are selected as a study based on the following table: 
Table 7: Number of Academic Energies Based on UA Based Jobs (2014)

\begin{tabular}{|c|c|c|c|c|}
\hline No. & $\begin{array}{c}\text { Public } \\
\text { Universities }\end{array}$ & Professor & $\begin{array}{c}\text { Associate } \\
\text { Professor }\end{array}$ & Lecturer \\
\hline 1 & $\begin{array}{c}\text { Universiti } \\
\text { Sultan Zainal } \\
\text { Abidin }\end{array}$ & 58 Person & 63 Person & 476 Person \\
\hline 2 & $\begin{array}{c}\text { Universiti } \\
\text { Malaysia } \\
\text { Terengganu }\end{array}$ & 105 Person & 229 Person & 180 Person \\
\hline 3 & $\begin{array}{c}\text { Universiti } \\
\text { Institut } \\
\text { Teknologi } \\
\text { MARA }\end{array}$ & 183 Person & 822 Person & 7884 Person \\
& & & \\
\hline
\end{tabular}

In general, promotion of academic staff is not based on vacancies. Their promotion should be based on the academic excellence that has been achieved by the staff as set out in the Lecturer Services Scheme under Malaysia's Remuneration System or New Remuneration System (Service Circular No. 1 Year 2016) [16]

\section{Sample Profile by Service Period}

Furthermore, in terms of length of the service, 63 persons (21.1\%) are consisted of 0 - 5 years, 100 persons (33.6\%) ranging from 6 10 years, 60 persons $(20.1 \%)$ ranging from $11-75$ people $(25.2 \%)$ more than 16 years old. This shows that most respondents involved in this study were primarily from 6 to 10 years of service.

Table 9: Sample Profile by Service Period

\begin{tabular}{|c|c|c|}
\hline & Quantity & Percentage \\
\hline 0-5 years & 63 & 21.1 \\
\hline 6-10 years & 100 & 33.6 \\
\hline 11-15 years & 60 & 20.1 \\
\hline 16 years and above & 75 & 25.2 \\
\hline Total & 298 & 100.0 \\
\hline
\end{tabular}

The duration of respondent's service shows variability from 0 to 16 years and above. This is the normal period for lecturer services. The duration of the service indicates that the study has taken the views of the fresh and veteran lecturers into account.

The findings showed that the number of respondents aged 6-10 years old are comprised of 100 people (33.6\%). However, 75 respondents $(25.2 \%)$ are those who have served at least 16 years and are categorised as a senior academic staff.

A competent academic staff needs to have extensive experience in a specific field and have served for a quite some time. In [28] argues that effective academic staff should devise new knowledge based on their past experiences and use their work experience in helping to improve student learning quality [28]. Hence, long-term academic staff is seen to have added value to the quality of teaching.

\section{Conclusion}

All the results of the demographic information of the respondents managed to assist researchers in analysing the demographic characteristics of the respondents from different walks of background and category. Furthermore, the studies on job satisfaction among academic staff will be carried out by taking account all the demographic characteristics of said respondents so that the outcome of the study can cover the views from all positions of the academic staff at public universities in Terengganu.

\section{Acknowledgement}

The authors would like to thank the Research Management, Innovation and Commercialization Centre, Universiti Sultan Zainal Abidin, Terengganu, Malaysia for providing the financial assistance to support the publication fee of this article.

\section{References}

[1] Unit Perancang Ekonomi. (2015). Mentransformasi sistem pendidikan, 39. 2015 yearly report. Jabatan Perangkaan Malaysia.

[2] Unit Perancang Ekonomi. (2015). Mentransformasi sistem pendidikan, 39. 2015 yearly report. Jabatan Perangkaan Malaysia

[3] Kementerian Pendidikan Tinggi Malaysia. (2015). Laporan Statistik Pendidikan Tinggi. Kementerian Pendidikan Tinggi Malaysia.

[4] National Higher Education of Malaysia. (2007). Pelan Strategik Pengajian Tinggi Negara. National Higher Education of Malaysia.

[5] Jabatan Perkhidmatan Awam Malaysia. (2015). Pekeliling Perkhidmatan Bilangan 13 Tahun 2011, pelaksanaan dasar pemisah (exit policy) dalam perkhidmatan awam. Jabatan Perkhidmatan Awam Malaysia.

[6] Kementerian Pembangunan Wanita, Keluarga dan Masyarakat. (2016) Laporan tahunan 2016, keterangkuman sosial ke arah kesejahteraan. Kementerian Pembangunan Wanita, Keluarga dan Masyarakat.

[7] Noah, S. M., Muhamad, M. H., \& Index, D. (1999). Kepuasan bekerja di kalangan pegawai tadbir Universiti Putra Malaysia di Serdang Selangor. Pertanika J. Soc. Sci and Humanities, 7(1), 59-70.

[8] The Straits Times, 5 March 2017.

[9] Robert, J. H., \& Lawrence A. W. (1959). Herzberg's dual-factor theory of job satisfaction and motivation: A review of the evidence and a criticism. Bernard M. Baruch School of Business and Public Administration.

[10] Kim, Q. W. (2000). Satu tinjauan tentang kepuasan kerja guru SJK(C) di Kuala Lumpur. Master thesis, Universiti Malaya.

[11] Aishah, B. A. T. (2004). Kepuasan kerja dan tekanan yang dihadapi oleh guru sekolah menengah. Universiti Putra Malaysia.

[12] Noorhafeza, H. A., \& Ferlis, B. (2010). Hubungan antara kecerdasan emosi, kepuasan kerja dan komitmen terhadap organisasi. Jurna Kemanusiaan, 16, 62-82.

[13] Muda, M. S., \& Omar, N. W. (2006). Model peramal kepuasan kerja pegawai perkhidmatan pendidikan di komuniti Pesisir Terengganu. International Journal of Management Studies, 13, 123-142.

[14] Nguyen, A., Taylor, J., \& Bradley, S. (2003). Relative pay and job satisfaction: Some new evidence. https://mpra.ub.unimuenchen.de/1382/1/MPRA_paper_1382.pdf.

[15] Azmi, I. A. G., \& Ahmad, W. S. W. (2008). Pengaruh sikap dan demografi ke atas produktiviti kerja pensyarah Muslim: Kajian di Universiti Malaya. Jurnal Syariah, 16(2), 321-344.

[16] Kementerian Pembangunan Wanita, Keluarga dan Masyarakat. (2016). Laporan tahunan 2016, keterangkuman sosial ke arah kesejahteraan. Kementerian Pembangunan Wanita, Keluarga dan Masyarakat.

[17] Ilhaamie, W. S. (2008). Pengaruh sikap dan demografi ke atas produktiviti kerja pensyarah Muslim: Kajian di Universiti Malaya. Jurnal Syariah, 16(2), 321-344.

[18] Azmi, I. A. G., \& Ahmad, W. S. W. (2008). Pengaruh sikap dan demografi ke atas produktiviti kerja pensyarah Muslim: Kajian di Universiti Malaya. Jurnal Syariah, 16(2), 321-344.

[19] Haryati, K. (2013). Faktor tekanan kerja dalam kalangan kakitangan. Bachelor thesis, Open University Malaysia.

[20] Nurita, J., Fatimah, P. W., Noor, A. O., \& Hanifah, M. (2010). Factors influencing internal and external employability of employees. Business and Economics Journal, 2, 1-10.

[21] Lortie-Lussier, M., \& Rinfret, N. (2010). Determinants of objective and subjective success of men and women. International Review of Administrative Sciences, 71(4), 607-624.

[22] Yu, C. (2012). Career success and its predictors: Comparing between Canadian and Chinese. International Journal of Business and Management 7(14), 88-95.

[23] Chen, Z., Veiga, J. F., \& Powell, G. N. (2011). A survival analysis of the impact of boundary crossings on managerial career advancement up to midcareer. Journal of Vocational Behavior 79(1), 230-240.

[24] Al-Mansor, A. S., \& Roziah, M. R. (2012). Tinjauan faktor-faktor pendorong kejayaan kerjaya ahli akademik: konteks universit penyelidikan di Malaysia. Jurnal Sosiohumanika, 5(2), 185-202.

[25] Buddeberg-Fischer, B., Stamm, M., Buddeberg, C., \& Klaghofer, R. (2008). Career-success scale: A new instrument to assess young physicians' academic career steps. BMC Health Services Research 8(120), 1-7.

[26] Prpic, K. (1996). Scientific fields and eminent scientist productivity patterns and factors. Scientomoteric, 42(1), 445-471.

[27] Jabatan Perkhidmatan Awam. (2016). Pekeliling Perkhidmatan Bilangan 1 Tahun 2016. Jabatan Perkhidmatan Awam.

[28] Nooraini, O., \& Khairul Anuar, A. R. (2010). Hubungan antara kompetensi pensyarah dengan pencapaian akademik pelajar. Universiti Teknologi MARA. 